\title{
Determinants of Childhood Malnutrition and Consequences in Developing Countries
}

\author{
Oluwole Steve Ijarotimi
}

Published online: 6 July 2013

(C) Springer Science+Business Media New York 2013

\begin{abstract}
Adequate nutrition is essential in early childhood to ensure normal growth, neurological and cognitive development, and healthy life. However, in many parts of developing countries this situation is not met as a result of poverty, lack of nutrition knowledge, poor childfeeding practices, lack of care by caregivers, and infection. Hence, there is increased malnutrition, which has resulted in high morbidity and mortality among children in developing countries. In view of this nutritional problem, there is a need for both national and international organizations to embark upon nutrition and women empowerment programmes in order to alleviate nutritional problems in developing counties and to achieve the Millennium Development Goals (MDGs), particularly those related to the eradication of extreme poverty and hunger (MDG 1) and child survival (MDG 4).
\end{abstract}

Keywords Childhood malnutrition · Consequences · Developing countries

\section{Introduction}

\section{Childhood Nutrition}

Adequate nutrition is defined as the intake and utilisation of enough energy and nutrients to maintain nutritional and health well-being [1]. Adequate nutrition is essential in early childhood to ensure normal growth, neurological and cognitive development, and healthy life [1]. Adequate feeding and access to appropriate quality and quantity of foods are essential components of optimal nutrition for children. Optimal infant and young child feeding can be achieved easily by

O. S. Ijarotimi $(\bowtie)$

Department of Food Science and Technology, Federal University of Technology, Akure, Nigeria

e-mail: soijarotimi@gmail.com encouraging mothers to breastfeed exclusively for the first 6 months and to introduce nutritionally adequate, safe, age appropriate, responsive complementary feeding starting at 6 months [2,3]. Earlier data suggest that adequate nutrition is important for growing children [4]. Evidence has shown that health in old age is associated with adequate nutrition and good health in earlier years of life [5]. Therefore, there is a need to introduce qualitative and quantitative foods at earlier ages for children.

\section{Childhood Malnutrition}

Malnutrition continues to be a major public health problem throughout the developing world, particularly in southern Asia and sub-Saharan Africa [6-8]. There is evidence that diets consumed in many parts of these developing countries are frequently deficient in macronutrients (protein, carbohydrates, and fat, leading to protein-energy malnutrition), micronutrients (minerals and vitamins, leading to specific micronutrient deficiencies), or both [9-11].

Dietary intakes of children in many parts of developing countries are basically plant-based, which are devoid of essential nutrients $[12,13]$. Foods given to children are low in energy-dense, protein and micronutrients, couple with insufficient intakes [14, 15]. Epidemiological studies have reported that prevalence of malnutrition among children is high due to poor child-feeding practices $[14,16]$. Solomon [17] reported that poor foods and poverty among households are the most important direct factors responsible for proteinenergy malnutrition. For instance, high cost of animal-based foods is beyond the reach of most families in developing countries $[12,18-20]$; hence, they depend on low-quality traditional foods. Scientific investigation reported that overdependence on such family diets, without adequate supplementation with high-quality protein sources is the main attributable factor for the widespread of protein-energy malnutrition in developing countries [21]. 
Micronutrients are nutrients needed in minute, specific quantities in the body, and they are not usually produce in the body but are derived from food intake. Worldwide, onethird of the population suffers from micronutrient deficiencies, due primarily to inadequate dietary intake [22]. A child whose food intakes are inadequate and solely from starch sources is likely to develop micronutrient malnutrition [23]. These micronutrients include vitamins A and B12, iron, folic acid, iodine, and zinc, which are increasing in developing countries with major adverse health consequences, contributing to impairments in growth, immune competence, and mental retardation among children that cannot be reversed by nutrition interventions [24]. In developing regions of the world, micronutrient deficiencies are common due to food insecurity and lack of dietary diversity [22]. Contrary to the developed countries whom are able to augment dietary their staples with micronutrient-rich foods, such as animal-based products and have greater access to a variety of fruits and vegetables, whereas in developing countries people tend to consume only small amounts of these foods, relying instead on more monotonous diets based on cereals, roots, and tubers. Developing countries' diets are predominantly dominated by plant-based foods, such as cereals, roots, and tubers, which limit the absorption of minerals due to their high phytate and polyphenol contents $[25,26]$. Hence, these foods can only provide a small proportion of the daily requirements for most vitamins and minerals.

\section{Determinant of Childhood Malnutrition in Developing Countries}

Malnutrition is caused by one or a combination of factors. The immediate determinants of child nutritional status are poor dietary intake (i.e., energy, protein, and micronutrients) and disease. These factors are interdependent. For instance, a child with inadequate dietary intake is more susceptible to disease, which in turn depresses appetite, inhibits the absorption of food nutrients, and competes for a child's energy [27]. Dietary intake must be adequate in quantity and quality, and nutrients must be appropriately consumed in right combinations for adequate absorption. The immediate determinants of child malnutrition are influenced by three underlying determinants, which are food security, adequate care for mothers and children, and a proper health environment, including access to health services [28-30]. Finally, the underlying determinants are influenced by the basic determinants: the potential resources available to a country or community, and a host of political, cultural, and social factors that affect their utilization.

Food security is achieved when a family has access to enough food to live an active and healthy life [31]. The resources necessary to gain access to food are food production, income for food purchases, or donors whether from other private citizens, national or foreign governments, or international institutions. However, many families in developing countries are food insecure due to low accessibility to quality and quantitative food. The second underlying determinant of child malnutrition is care, which is the provision by caregivers of "time, attention, and support to meet the physical, mental, and social needs of the growing child and other household members" [32]. Caring for a child involves timely child feeding, health- seeking behaviors, support, and cognitive stimulation for children. The adequacy of such care is determined by the caregiver's control of economic resources, autonomy in decision making, knowledge, and beliefs. The third under lying determinant of child nutritional status - health environment and services - rests on the availability of safe water, sanitation, health care, and environmental safety, including shelter $[29,30]$.

The main factor that affects all underlying determinants is poverty. A person is considered to be in absolute poverty when he or she is unable to adequately satisfy his or her basic needs - such as food, health, water, shelter, primary education, and community participation [33]. Poverty is the main underlying cause of poor nutrition in some parts of developing countries [34,35]. The effects of poverty on child malnutrition are pervasive. Poor households and individuals are unable to achieve food security, have inadequate resources for care, and are not able to utilize (or contribute to the creation of) resources for health on a sustainable basis [33]. Poverty has a vicious cycle; it leads to inadequate food intake, undernutrition, poor physical growth and development, impaired functioning, and low productivity. Poverty imposes restrictions on food intake of poorer sections of society and the worst sufferers are reproductive age women, including young children and adolescents [36]. Poverty is associated with poor nutrition practices; hence, a large proportion of the poor-resource mothers depend on low-quality traditional foods to feed their children [37]. Diets in populations are frequently deficient in macronutrients (protein, carbohydrates and fat, leading to protein-energy malnutrition), micronutrients (electrolytes, minerals, and vitamins, leading to specific micronutrient deficiencies), or both [8-11].

\section{Trend in Prevalence of Childhood Malnutrition in Developing Countries}

In developing countries, the prevalence of child malnutrition has been progressively declining [38]. It was reported that the prevalence of underweight children in 1990 was 159 million (25\%) globally and out of which developing countries was 158 million (29\%). In 2010, the prevalence declined to 102 million (16\%) globally, whereas that of developing countries was 101 million $(18 \%)$. Similar trend was observed for stunting in 1990 the prevalence of stunting globally was 253 million children (40\%), and out of which developing countries was 248 million $(45 \%)$. The decline pace of child 
malnutrition in developing countries showed that fairly substantial progress has been made during the past 20 years. Epidemiological studies have reported that the pace of progress varied among the regions, for instance, accelerated progress was observed in South Asia; whereas number of malnourished children increased in Sub-Saharan Africa [39]. Since 1970, underweight rates decreased for 35 developing countries, held steady in 15 , and increased for 12 , with most of the latter countries being in Sub-Saharan Africa [39].

Micronutrient malnutrition is a widespread public health problem in developing nations because of the large numbers of people that are affected and also is a risk factor for many diseases. It contributes to high rates of morbidity and even mortality among the children. For instance, vitamin A deficiency affects more than 130 million preschool children and is the leading preventable cause of childhood blindness and major underlying cause of child mortality in developing countries [40]. Iron deficiency lead to poor physical growth and cognitive development, which affects school performance and productivity of the child at adulthood [41, 42].

\section{Consequences of Childhood Malnutrition}

Malnutrition in the form of undernutrition is the most significant risk factor for the burden of disease in developing countries [43, 44], causing approximately 300,000 deaths per year accountable for more than half of the deaths occurring in children in the developing countries [45-47]. Malnutrition causes a great deal of human suffering physically and emotionally. It is a violation of a child's human rights and a major waste of human productivity. Health consequences of inadequate nutrition are enormous [47]. It is estimated that malnutrition alone accounts for more than half of children's deaths annually [48]. In developing countries, approximately 183 million children are underweight-for-age, 67 million are underweight-for-height (wasted), and 226 million are low height-for-age (stunted) [48]. Evidence has shown that malnutrition is associated with more than half of all children's deaths worldwide [49] and that children who suffered malnutrition are less physically and intellectually productive at adulthood [50]. It has been documented that malnutrition in young children causes disturbances in the morphological and functional development of the central nervous system, thus affecting the cognitive and emotional development of the child [51]. Both protein-energy and micronutrient malnutrition have profound negative consequences for children' health and survival.

Micronutrient deficiencies, particularly iodine and iron, have been implicated to impair growth and cognitive development in children. Iodine deficiency adversely affects development of the central nervous system. A study indicates that individuals with an iodine deficiency had, on average, 13.5 points lower IQs than comparison groups [52]. ACC/SCN
[53] reported that globally approximately 2 billion people are affected by iodine deficiency, including 285 million children aged 6 to 12 years. Adequate iron intake also is necessary for brain development. More than $40 \%$ of children ages $0-4$ years in developing countries suffer from anemia [53]. Anemia in school-age children also may affect school performance whether or not there had been earlier impaired brain development.

In most developing countries, the synergistic relation between malnutrition and infectious diseases remains the most important immediate cause of death among children and of disability worldwide $[54,55]$. It has been estimated that problems involving interaction of malnutrition and infection affect children worldwide and account for majority of illness and deaths recorded in them [9]. Malnutrition causes an increased susceptibility to infections; the latter leads to increased requirement for nutrients by hypercatabolism and increased loss of body constituents subsequently. Often, there is additional decrease in dietary intake, and together, these can result in precipitation of acute deficiency states in the under-fives who are marginally compensated before the infections. There are noticeable disparities between children from developed countries and those from poor-resource countries. For instance, children from developing countries, who are mostly malnourished, suffer more from underweight, stunting, impaired cognitive function, poor school performances, higher risk of infection, ill health, and death than their counterparts of normal nutritional status from developed countries $[56,57]$. The most severe effects of malnutrition are more in children ( $<5$ years) even; if nutrition improves from that time forward, they are most likely to suffer from below-normal growth, which would affect their physical and mental development, thereby compromising the future of these children, their communities, and their countries at large.

\section{Strategies for Reducing Childhood Malnutrition in Developing Countries}

There are three basic conditions to prevent malnutrition in children: adequate food availability and consumption; good health and access to medical care; and adequate feeding practices; and if any one of these is absent, protein-energy malnutrition is a likely outcome [58]. Countries need to adopt and support a comprehensive approach that addresses the causes of malnutrition in children. Actions should be put in place to promote the supply, access, consumption, and utilization of an adequate quantity, quality, and variety of foods for all populations groups.

Caregivers might not make the best use of these available resources because of lack of knowledge of optimal feeding practices and inappropriate cultural beliefs and practices regarding complementary feeding [59-61]. In developing countries children often are weaned on starchy, bulky gruels, which have both low energy and nutrient density. It is well 
known that plant-based complementary foods are usually insufficient to meet the protein and certain micronutrients requirements of growing children [62, 63].

Globally, progress is being made to reduce undernutrition [64]. The challenge of child undernutrition in developing countries, particularly Africa, is immense [65]. In order to reduce malnutrition problem among children in developing countries, it is important that caregivers be provided access to food, and in addition improving the caregiver's knowledge on food utilization and proper childcare, and caregiver's own health status and control over resources within the household that might be used to care for children are being encouraged [66]. Finally, the level of access to information on and services for maintaining health, whether preventive and curative health services are available, and the presence or absence of a healthy environment with clean water, adequate sanitation, and proper shelter [66] also are parts of the facilities to put in place by the national government to improve the child nutritional status.

\section{Conclusions}

It is well known that cases of childhood malnutrition are quite high in developing countries. Several factors, such as poverty, poor child feeding practices, lack of nutrition education among nursing mothers or caregivers, and poor health care facilities, have been identified as the most important risk factors. In view of this, there is a need for national and international organizations and public health officials to continue embarking on women empowerment programs to eradicate poverty among women, which would have positive impacts on the nutritional and health wellbeing of children in developing countries.

\section{Compliance with Ethics Guidelines}

Conflict of Interest Oluwole Steve Ijarotimi declares that he has no conflict of interest.

Human and Animal Rights and Informed Consent This article does not contain any studies with human or animal subjects performed by any of the authors.

\section{References}

1. FMOH. National policy on infant and young child feeding in Nigeria. 2005; 1-25.

2. Martorell R, Kettel KL, Schroeder DG. Reversibility of stunting: epidemiological findings in children from developing countries. Eur J Clin Nutr. 1994;48:S45-57.

3. WHO. Complementary feeding: report of the global consultation. Summary of guiding principles for complementary feeding of the breastfed child. Geneva: WHO; 2001.
4. Lutter C. Meeting the challenge to improve complementary feeding. In: Moreira (ed). Meeting the challenge to improve complementary feeding. SCN News. UK: UN Systems Standing Committee on Nutrition, Lavenhem Press; 2003. p. 4-10.

5. WHO. World Health Day-toolkit for organizers. Available from :http;// www.who.int/world-health-day/2012/toolkit/background/en/ index.html.

6. Schofield C, Ashworth A. Why have mortality rates for severe malnutrition remained so high? Bull World Health Organ. 1996;74:223-9.

7. FAO. (Food and Agriculture Organization) of the United Nations. Undernourishment around the world. In: The state of food insecurity in the world 2004. Rome: The Organization; 2004.

8. Brabin BJ, Coulter JBS. Nutrition-associated disease. In: Cook GC, Zumla AI, editors. Manson's tropical diseases. London: Saunders; 2003. p. 561-80.

9. Pinstrup-Andersen P, Burger S, Habicht JP, Peterson K. Protein-energy malnutrition. In: Jamison DT, Mosley WH, Measham AR, Bobadilla JL, editors. Disease control priorities in developing countries. 2nd ed. Oxford (UK): Oxford University Press; 1993. p. 391-420.

10. Levin HM, Pollitt E, Galloway R, McGuire J. Micronutrient deficiency disorders. In: Jamison DT, Mosley WH, Measham AR, Bobadilla JL, editors. Disease control priorities in developing countries. 2nd ed. Oxford (UK): Oxford University Press; 1993. p. $421-51$.

11. Millward DJ, Jackson AA. Protein/energy ratios of current diets in developed and developing countries compared with a safe protein/ energy ratio: implications for recommended protein and amino acid intakes. Public Health Nutr. 2004;7:387-405.

12. Mosha TCE, Laswai HS, Tetens I. Nutritional composition and micronutrient status of homemade and commercial weaning foods consumed in Tanzania. Plant Foods Hum Nutr. 2000;55(3):185205.

13. Nnam NM. Evaluation of Complementary Foods based on Maize, Groundnut, Pawpaw and Mango flour Blends. Niger J Nutr Sci. 2002;22\&23:8-18.

14. Anigo KM, Ameh DA, Ibrahim S, Danbauchi SS. Infant feeding practices and nutritional status of children in North Western Nigeria. Asian J Clin Nutr. 2009;1(1):12-22.

15. Villapando S. Feeding mode, infections, and anthropometric status in early childhood. Pediatrics. 2000;106:1282-3.

16. Li R, Rock VJ, Grummer-Strawn L. Changes in public attitudes toward breastfeeding in the United States, 1999-2003. J Am Diet Assoc. 2007;107:122-7.

17. Solomon M. Nutritive value of three potential complementary foods based on cereals and legumes. Afr J Food Nutr Sci. 2005;5(2):1-14.

18. Amankwah EA, Barimah J, Acheampong R, Addai LO, Nnaji CO. Effect of Fermentation and Malting on the Viscosity of MaizeSoyabean Weaning Blends. Pak J Nutr. 2009;8(10):1671-5.

19. Bruyeron O, Denizeau M, Berger J, Trèche S. Marketing complementary foods and supplements in Burkina Faso, Madagascar, and Vietnam: Lessons learned from the Nutridev program. Food Nutr Bull. 2010;31(2):S154-67.

20. Muhimbula HS, Issa-Zacharia A, Kinabo J. Formulation and sensory evaluation of complementary foods from local, cheap and readily available cereals and legumes in Iringa, Tanzania. Afr J Food Sci. 2011;5(1):26-31.

21. Kikafunda JK, Abenakyo L, Lukwago FB. Nutritional and sensory properties of high energy/nutrient dense composite flour porridges from germinated maize and roasted beans for child-weaning in developing countries: a case for Uganda. Ecol Food Nutr. 2006:45:279-94.

22. Dewey KG, Brown KH. Update on technical issues concerning complementary feeding of young children in developing countries and implications for intervention programmes. Food Nutr Bull. 2003;24:5-28. 
23. Fiedler JL, Macdonald B. A strategic approach to the unfinished fortification agenda: Feasibility, costs, and cost effectiveness analysis of fortification programs in 48 countries. Food Nutr Bull. 2009;30(4):283-311.

24. Viteri FE, Gonzalez H. Adverse outcomes of poor micronutrient status in childhood and adolescence. Nutr Rev. 2002;60:S77-83.

25. Hurrell R, Ranum P, de Pee S, Beibinger R, Hulthein L, Johnson Q, et al. Revised recommendations for iron fortification of wheat flour and an evaluation of the expected impact of current national wheat flour fortification programs. Food Nutr Bull. 2010;31(1):S7S21.

26. Hurrell R. How to ensure adequate iron absorption from ironfortified food. Nutr Rev. 2002;60:S7-15. discussion S43.

27. Gafar TI, Abdulrazaq AY, Usman AR. Determinanat of child undernutrition in Sub-Saharan Africa: Empirical evidence from cross country analysis. Glob J Finance Econ. 2005;2(2):221-32.

28. Engle P, Menon P, Had dad L. Care and nutrition: Concepts and measurement. World Dev. 1999;27(8):1309-37.

29. UNICEF (United Nations Children's Fund). Strategy for improved nutrition of children and women in developing countries. New York; 1990

30. UNICEF. The state of the world's children. New York; 1998.

31. World Bank. Poverty and hunger: Issues and options for food security in developing countries. Washington, D.C.; 1986.

32. ICN (International Conference on Nutrition). Caring for the socioeconomically deprived and nutritionally vulnerable. Major Issues for Nutrition Strategies Theme Paper no. 3. ICN/92/INF/7. Rome: Food and Agriculture Organization of the United Nations and World Health Organization; 1992.

33. Frankenberger TR. Measuring house hold livelihood security: an approach for reducing absolute poverty. Food Forum. 1996;34:1-5.

34. Duncan T. Commission on Macroeconomics and Health. Health, nutrition and economic prosperity: a microeconomic perspective. CMH working paper no WG1:7. Geneva: World Health Organization; 2001.

35. Sachs JD, McArthur JW. The Millennium Project: a plan for meeting the Millennium Development Goals [published erratum appears in Lancet 2005; 365:1138. Lancet. 2005;365:347-53 (erratum, $365: 1138$ )

36. World Bank Report. Official Home page of World Bank. http:// www.world bank.org. Retrieved on December 25, 2006.

37. Eka BE, Abbey BW, Akaninwor JO. Nutritional evaluation of some traditional weaning foods from Akwa Ibom State, Nigeria. Niger J Biochem Mol Biol. 2010;25(1):65-72.

38. UNICEF/WHO. United Nations Children's Fund, World Health Organization, The World Bank. UNICEFWHO-World Bank Joint Child Malnutrition Estimates. UNICEF, New York; WHO, Geneva; The World Bank, Washington, DC; 2012.

39. WHO. WHO global database on child growth and mal nutrition. Programme of Nutrition. WHO Document No. WHO/NUT/97.4. Geneva; 1997.

40. West KP Jr, Klemm O, Dary Q, Johnson P, Randel C. Northrop Cleves. Vitamin A fortification group. Background document prepared for the second technical workshop on wheat flour fortification Atlanta, G. A. 31st March-3 April, 2008. Draft 31 March, 2008.

41. Miguel E, Kremer M. Worms: Identifying Impacts on education and Health in the Presence of Treatment Externalities. Econometrica. 2004;72(1):159-217.

42. Lozoff B. Iron deficiency and child development. Food Nutr Bull. 2007;28:S560-71.

43. Murray CJL, Lopez AD. Global mortality, disability, and the contribution of risk factors: Global Burden of Disease Study. Lancet. 1997;349:1436-42.

44. Nemer L, Gelband H, Jha P. Commission on Macroeconomics and Health. The evidence base for interventions to reduce malnutrition in children under five and school-age children in low- and middleincome countries. CMH working paper no WG5:11. Geneva: World Health Organization; 2001.

45. Müller O, Garenne M, Kouyaté B, Becher H. The association between protein-energy malnutrition, malaria morbidity and allcause mortality in West African children. Trop Med Int Health. 2003;8:507-11.

46. Black RE, Morris SS, Bryce J. Where and why are 10 million children dying every year? In Lancet. 2003;361:2226-34.

47. Oshaug A, Eide WB, Eide A. Human rights: A normative basis for food and nutrition- relevant policies. Food Policy. 1994;19(no. 6):491-516

48. World Health Organization. World Health Statistics Report. Geneva, Switzerland; 2011.

49. Pelletier DL, Frongillo EA. Changes in child survival are strongly associated with changes in malnutrition in developing countries. J Nutr. 2003;133(1):107-19.

50. REAP Health, Nutrition, Care and Educational Performance. 2010. Available at: http://reap.stanford.edu/docs/nutrition_and_education. Accessed 10/2/20112.

51. Northstone K, Joinson C, Emmet P, Ness A, Paus T. Are dietary patterns in childhood associated with IQ at 8 years of age? A population-based cohort study. J Epidemiol Community Health. 2010;66(7):624-8. 02/2011.

52. Grantham-McGregor S, Fernald L, Sethuraman K. Effects of Health and Nutrition on Cognitive and Behavioural Development in Children in the First Three Years of Life. Part 2. Infections and Micronutrient Deficiencies: Iodine, Iron and Zinc. Food Nutr Bul. 1999;20(1):76-99.

53. ACC/SCN (Administrative Committee on Co ordination/SubCommittee on Nutrition). Second report on the world nutrition situation, vol. I. Geneva: United Nations; 1992.

54. Lambrechts T, Bryce J, Orinda V. Integrated management of childhood illness: a summary of first experiences. Bull World Health Organ. 1999;77:582-94.

55. Tulloch J. Integrated approach to child health in developing countries. Lancet. 1999;354:16-20.

56. Smith LC, Haddad L. Explaining child malnutrition in developing countries: A cross-country analysis. IFPRI FCND Discussion Paper No. 60. Washington, D.C: IFPRI; 1999.

57. Alderman H, Hoogeveen H, Rossi M. Preschool Nutrition and Subsequent Schooling Attainment: Longitudinal Evidence from Tanzania. Econ Dev Cult Chang. 2009;57(2):239-60.

58. de Onis M, Frongillo EA, Blossner M. Is malnutrition declining? An analysis of changes in levels of child malnutrition since 1980. Bull World Health Organ. 2000;78(10):1222-32.

59. Allen LH, Gillespie SR. What works? A review of the efficacy and effectiveness of nutrition intervention. ACC/SCN Nutrition Policy Paper. 2001;19:27-8.

60. Engle PL. Infant feeding styles: Barriers and opportunities For good nutrition in India. Nutr Rev. 2002;60(5 pt2):S109-14.

61. Moore AC, Akhter S, Aboud FE. Responsive complementary feeding in rural Bangladesh. Soc Sci Med. 2006;62:1917-30.

62. Ibe BC. Feeding of infants and children with special needs and challenges. Proceedings of the Adequate Infant Nutrition Conference, Lagos. 2008:18-23.

63. Nwamarah JU, Amadi VO. Chemical and sensory evaluation of complementary foods for infants (6-24months) using locally available Nigerian staples. Niger J Nutr Sci. 2009;30(1):112-5.

64. United Nation. The millennium development goals report 2012, New York. 2012:1-72.

65. International Food Policy Research. Institute Official home page of International Food Policy Research Institute. 2005. http://www.ifpri.org. Retrieved on April 16, 2013.

66. Gulati JK. Child Malnutrition: Trends and Issues Kamla-Raj. Anthropologist. 2010;12(2):131-40. 